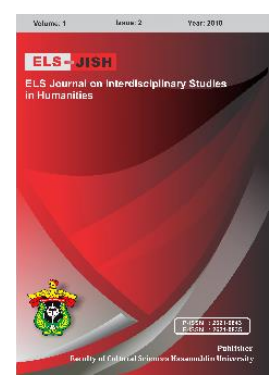

ELS-JISH

ELS Journal on Interdisciplinary Studies on Humanities

Volume 1 Issue 2, 2018

ISSN (print) : 2621-0843

ISSN (online) : 2621-0835

Homepage : http://journal.unhas.ac.id/index.php/jish

\title{
Symbol and Meaning of Kapata Oral Tradition Texts in Central Maluku
}

\author{
Prihe Slamatin Letlora ${ }^{1}$
}

e-mail:priheletlora22@gmail.com

\begin{abstract}
The purposes of this research were (1) to reveal the kinds of symbols that applied in the texts of Kapata in Central Maluku and (2) to map out the meanings of the symbols. The data of this research was taken from texts of Kapata in Saparua Island, Central Maluku. The texts were obtained from field research through the process of observation, library research and interview. All obtained data were analyzed with descriptive qualitative analysis. The results of this research explained that (1) in Saparua Island, types of symbols found were Lexical Symbols (Noun and Adjective), Phrasal Symbols (Verb Phrase and Noun Phrase), Clausal Symbol (Dependent Clause) and Sentential Symbol; and (2) it is obviously seen that Kapata generally contained either denotative or denotative - connotative meanings.
\end{abstract}

Keywords: : Oral Tradition Text, Kapata, Symbols, Meaning

How to cite: Letlora, P, S. (2018). Symbol and Meaning of Kapata Oral Tradition Texts

in Central Maluku. ELS Journal on Interdisciplinary Studies in Humanities, 1 (2), 153-161.

\section{Introduction}

Language plays a significant role to determine all kinds of activities and behaviors of human. One particular activity of human in a need of language is to communicate with others. According to Sapir (1921: 10), language is purely human and non-instinctive method of communicating ideas, emotions and desires by means of voluntarily produced symbols. Through this process, human is able to convey the message.

Furthermore, language and culture are like a piece of paper that cannot be separated each other. Language is the ability to acquire and use complex systems of communication, particularly the human ability to do so, and a language is any specific example of such a system. Thus, humans are gifted to convey message and to communicate one another by using language. According to Taylor, culture determines as the group of human activities including knowledge, history, belief, art, moral, and other tradition (in Latupapua, 2012:1). Culture generally consists of folksong, dances, games, and folklore that basically is determined as the living expression, developed and becoming famous in particular local ethnic.

Furthermore, literature is determined as human activities in particular media and has particular aesthetic characteristics as well. Therefore we can say that literature has an

${ }^{1}$ Taman Budaya Maluku 
ability to represent human cultures. Speaking of literature, according to Teeuw (2003: 33) it is divided into two main parts which are oral literature and written literature. Oral literature is a form of literature that uses utterances or verbal language by the process of direct communication. In the other side, written literature uses written media. He adds that it appeared in early century when human firstly begun to recognize and to use alphabet and symbols in the way of communicating, therefore writing has become a medium in literature communication between creator and the audience (2003: 229). Moreover, Vansina (2014) states that oral literature is directly related to a particular process and considered as a result of the process, itself. It can consist of oral messages based on the previous messages from at least one generation. Oral literature or folk literature corresponds in the sphere of the spoken (oral) words to literature as literature operates in the domain of the written word. He adds that oral tradition, or oral lore is a form of human communication where in knowledge, art, ideas and cultural material is received, preserved and transmitted orally from one generation to another.

According to George (in Petrus 2012: 4) the ability to apply signs or symbols makes human able to see his/herself through other's perspectives. Processes of thinking, reacting and interacting are possible since important symbols in social group have the same meanings and trigger the same reaction for those who use the symbols. Thus, it can be stated that in a process of social interaction, human communicates meaning to other human through symbols. Afterwards, they will interpret the symbols and act based on that. Theoretically, meaning is a thing, an existing thing from human behavior and symbols that used in the implementation of human culture. Meaning is said to be a manifestation or the form of what human use and do. Peirce (1931-58), a sign is something that can be interpreted as having a meaning, which is something other than itself, and which therefore able to communicate information to the one interpreting or decoding the sign. Sign can work through any of the senses, visual, auditory, tactile, and taste, and their meaning can be intentional such as a word uttered with a specific meaning. Peirce applies Saussure's theory of semiotics whereas a sign has signifier and signified. Zimmer (1969) gives a deeper understanding that concepts and words are symbols, just as visions, rituals, and images are the manners and customs of daily life. He also adds that there are so many metaphors reflecting and implying something. Symbols hold the mind to truth but are not themselves the truth. From this point of view, it is logically assumed that the possibility of conducting research on symbols in frame of semiotics in culture is higher.

Central Maluku is recognized as one of the parts of Maluku province that has oral tradition named Kapata. Moreover, Kapata can be identified as genre of folklore that mainly found in cultural ritual in some cultural villages such as the coronation of king, the inauguration of Baileo (the traditional house of Maluku built up from woods) and so on. Generally, Kapata is only mastered by the elders who have the important roles in custom. Kapata is mainly contained about history, advises, worship, the places in mythology of Maluku and any other philosophies of Maluku (Letlora, 2016).

Nowadays, Kapata has been considered as the endangered tradition due to the lack of speaker, minimum number on documentation and poor understanding on symbol and the meaning. Thus, it is needed to describe further about it in forms of researches to investigate more about it so people of Maluku may understand and maintain it as the treasure of Maluku. 


\section{Method}

This research applies method of descriptive qualitative research. It usually emphasizes words rather than quantification in the collection and analysis of data.

\subsection{Data Collection}

The data of this research are texts of Kapata oral tradition in Saparua island, Central Maluku. Saparua island is considered as one of the parts of Central Maluku that has a dynamic custom life and this is indicated that the use of Kapata may arise. Data collection is conducted through some techniques, such as: 1) figure out the symbols of Kapata; 2) the obtained data will be used to investigate the meanings of symbols.

\subsection{Data Analysis}

The data is analyzed by using the frame of descriptive qualitative approach. To analyze the data, the researcher used some techniques: firstly, the identified data from Kapata in Tana language and Ambonese Malay are selected and translated into English. Secondly, the texts will be tabulated based on their category. Thirdly, data might be analyzed by using semiotic approach. Finally, the obtained data will be analyzed to find the meanings of the symbol.

\section{Findings}

There were some texts of Kapata found in Saparua namely: 1) Kapata nasehat par ana cucu (Kapata of advice for children and grandchildren); 2) Kapata janji mama deng bapa (Kapata of promise to father and mother); 3) Kapata undang nyora-nyora par manari (Kapata of inviting the women in village to dance); 4) Kapata inga cewe (Kapata for remembering a lover) and 5) Kapata Gunung Iha (Kapata of Mount Iha). Here are the circumstances where each Kapata is used:

a. Kapata nasehat par ana cucu (Kapata of Advice for Children and grandchildren)

bae tarbae (good or bad)

simpan dalam hati e (keep it in your heart)

pulang ke rumahmu (coming back to your home)

jangan subu nama beta e (don't mention my name)

jangan subu nama beta e (don't mention my name)

oh jangan bikin salah e (oh don't make a mistake)

e gandong basudara e (my brother and sister)

This Kapata is usually performed when parents or the elders of one family gathers around with the children or the youth. It is categorized as Regular Kapata since the situational setting is only in regular occasion such as family gathering. The content is purpose is to give advises to young people so it is categorized as Kapata of advice.

b. Kapata undang nyora-nyora par manari (Kapata of inviting the women in village to dance) 


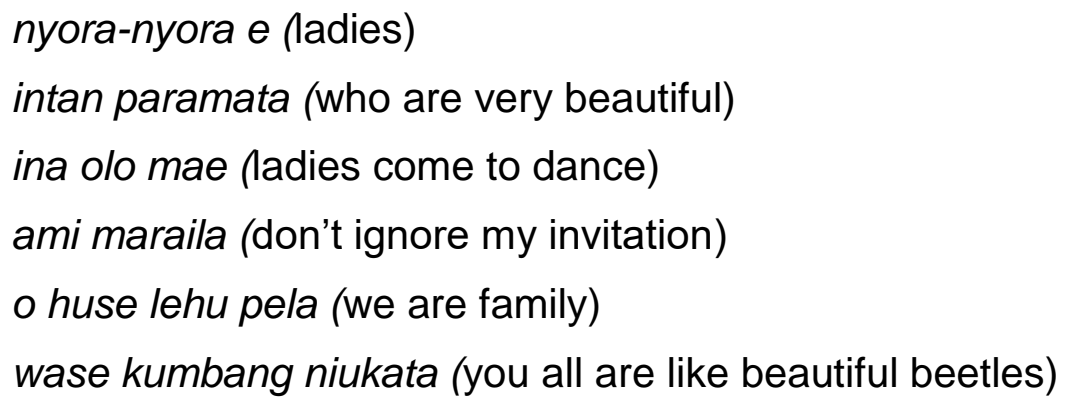

This Kapata is performed to invite all women who attend the party or custom ceremony to dance. Based on the content and situation it can be said that this Kapata is in the category of considered as Regular Kapata for ceremonial occasion.

c. Kapata inga cewe (Katapa for remembering a lover)

malakao sei (I am moaning how can I see you)

sei amboina e (you, who are in Ambon)

ami malwa sei pame seminia (I want to meet my girlfriend)

manuhata tura (but I cannot)

koku lima yapakali (put five fingers on my head)

'Kapata inga cewe' is categorized Kapata of affection from its content. It describes about the regretness of a man who cannot meet his lover. Based on the situational setting, this Kapata is categorized as Regular Kapata since the situation is the ordinary situation where young people sit together to celebrate or talk about their love.

d. Kapata Gunung Iha (Kapata of Mount Iha)

kuru e - kuru e, kuru manu kuru e (down, down, down, rooster comes down) ioto buang hola hale (totobuang has rang)

hale luma pesta e (let us go to the party)

This Kapata means before starting any kinds of rituals or custom ceremonies such as the King inauguration, in Nolloth, Kapata singer or namely Kewang must sing this Kapata more than once in order to invite spirit of the ancestors who live in the former village of Nolloth to join the occasion. Based on the situational setting, this Kapata is categorized as Customary Kapata. On its content, this Kapata is described as Kapata of Worship.

e. Kapata Janji Kapitan (Kapata of Kapitan)

sei tele-tele (we are gathering here)

ehe lotto mena (to make a promise)

yana waaria e sa (one shall not put away others)

kele-kele emu Uhuna sisario (we must put hand in hand)

o sari luako (do not put away others)

e sa teheelu (same position) 
This Kapata tells us about the promise of Kapitan or the army leader toward the villagers to protect the village from the enemies.

\section{Discussion}

Dealing with it, based on the findings, researcher formulates syntactic categories of symbols namely lexical symbol, phrasal symbol, clausal symbol and sentential symbol. Lexical symbol category contains symbols in form of words (Noun-N, Adjective-Adj., Verb$\mathrm{V}$, Adverb-Adv, and Preposition-P). Phrasal symbol category describes symbols in form of phrases (Noun Phrase-NP, Verb Phrase-VP, Adjective Phrase-AdjP and Prepositional Phrase-PP). Clausal symbol is in form of independent clause (IC) and dependent clause (DC). Finally, symbols may also find in sentential form, therefore it is called as Sentential Symbol.

1. Kapata nasehat par ana cucu (Kapata of advice for children and grandchildren)

\section{The symbols:}

Symbols represented in this text are Sentential Symbols.

\begin{tabular}{cccc} 
Signifier & Meaning & Signified & $\begin{array}{c}\text { Type of } \\
\text { Symbol }\end{array}$ \\
\hline $\begin{array}{c}\text { bae tarbae, } \\
\text { simpan } \\
\text { dalam hati }\end{array}$ & $\begin{array}{c}\text { Good or bad } \\
\text { keep in your } \\
\text { heart }\end{array}$ & $\begin{array}{c}\text { The acceptance } \\
\text { of someone's } \\
\text { weaknesses or } \\
\text { strength }\end{array}$ & $\begin{array}{c}\text { Sentential } \\
\text { Symbol }\end{array}$ \\
\hline $\begin{array}{c}\text { pulang ke } \\
\text { rumahmu, } \\
\text { jangan } \\
\begin{array}{c}\text { subu nama } \\
\text { beta e' }\end{array}\end{array}$ & $\begin{array}{c}\text { Back to your } \\
\text { mention my } \\
\text { name }\end{array}$ & $\begin{array}{c}\text { Any badness is } \\
\text { better being put } \\
\text { secretly. Do not } \\
\text { mention my } \\
\text { badness as a } \\
\text { public }\end{array}$ & $\begin{array}{c}\text { Sentential } \\
\text { Symbol }\end{array}$ \\
\hline
\end{tabular}

a) bae tarbae

(Good or bad)

Adj

b) pulang ke rumahmu

(Back to your home)

$$
\mathrm{V}+\text { Prep+Pos+N }
$$

simpan dalam hati e

(keep in your heart)

V+Prep+Pos.+N

jangan subu nama beta e

(do not mention my name)

$$
\mathrm{V}+\text { Pos. }+\mathrm{N}
$$

\section{The meaning (Denotation and Connotation)} heart.

"bae tarbae simpan dalam hati $e$ " means whether it is good or bad keep it in your 
"pulang ke rumahmu, jangan subu nama beta e" means come back home to your home do not mention my name.

This Kapata connotatively teaches us on how people in Maluku perceive the relationship among them as the relationship of a family, that as a one big family we are not allowed to mention someone's badness.

2. Kapata undang nyora-nyora par manari (Kapata of inviting the women in village to dance)

\section{The symbols:}

In its text, there are some identified Lexical symbols in forms of Noun and Adjective and Phrasal symbol in Noun Phrase:

\begin{tabular}{|c|c|c|c|}
\hline Signifier & Meaning & Signified & Type of Symbol \\
\hline $\begin{array}{c}\text { Intan } \\
\text { paramata }\end{array}$ & $\begin{array}{l}\text { Diamond, } \\
\text { jewel }\end{array}$ & $\begin{array}{l}\text { beautiful; } \\
\text { gorgeous }\end{array}$ & $\begin{array}{c}\text { Lexical Symbol } \\
\text { (Adj) }\end{array}$ \\
\hline Kumbang & Beetles & Beauty & $\begin{array}{l}\text { Lexical Symbol } \\
(\mathrm{N})\end{array}$ \\
\hline $\begin{array}{c}\text { Nyora-nyora } \\
\text { e intan } \\
\text { paramata }\end{array}$ & $\begin{array}{c}\text { Ladies like } \\
\text { diamond and } \\
\text { jewel }\end{array}$ & Beautiful women & $\begin{array}{c}\text { Phrasal } \\
\text { Symbol } \\
(\mathrm{NP})\end{array}$ \\
\hline $\begin{array}{c}\text { Wase } \\
\text { kumbang } \\
\text { niukata }\end{array}$ & $\begin{array}{l}\text { You are like } \\
\text { beautiful } \\
\text { beetles like }\end{array}$ & $\begin{array}{l}\text { You have good- } \\
\text { look }\end{array}$ & $\begin{array}{c}\text { Phrasal } \\
\text { Symbol } \\
(\mathrm{NP})\end{array}$ \\
\hline
\end{tabular}

a) Nyora-nyora e intan paramata

(Beautiful Women)

$\operatorname{Adj}+\mathrm{N}$

b) Wase kumbang niukata

(You are like beautiful beetles)

Adj+N

\section{The meaning (Denotation and Connotation)}

This Kapata is performed to invite all women who attend the party or custom ceremony to dance. Intan paramata denotatively means "intan Permata" or jewel and diamond, or something precious. Connotatively, this means beautiful. The figurative language used is symbolism meaning that diamond and jewel are used to symbolize how beautiful and good-look the women are. 
Meanwhile wase kembang niukata refers to the women as well. In this phrase, the speaker of Kapata uses personification "the beetles" to refer to "the women". He adds and also emphasizes that the women is not wonderful and beautiful only as the jewel and diamond but also as the beetles.

3. Kapata inga cewe (Kapata for remembering a lover)

The symbols:

The symbol obtained is Phrasal Symbol in form of Verb Phrase.

\begin{tabular}{cccc} 
Signifier & Meaning & Signified & Type of Symbol \\
\hline $\begin{array}{c}\text { Koku lima } \\
\text { yapakali }\end{array}$ & $\begin{array}{c}\text { Put five } \\
\text { fingers on the } \\
\text { head }\end{array}$ & $\begin{array}{c}\text { The } \\
\text { regretness }\end{array}$ & $\begin{array}{c}\text { Phrasal symbol } \\
\text { (VP) }\end{array}$ \\
\hline
\end{tabular}

Koku lima yapakali

(Put five fingers on the head)

$\mathrm{V}+\mathrm{Adj}+\mathrm{N}+$ Prep.+N

\section{The meaning (Denotation and Connotation):}

This Kapata is Kapata of Affection. It tells us about the passion of a man to meet his girlfriend in Ambon. At that time, Ambon is far away from Ullath village. However, the singer cannot explain further about the causes. 'koku lima yapakali' means that put five finger on the head as the symbol of regret. Then this Kapata is a symbol of regret of a man.

4. Kapata Gunung Iha (Kapata of Mount Iha)

\section{The symbols}

From the text, it can be identified some Lexical Symbols in Noun, such as:

\begin{tabular}{|c|c|c|c|}
\hline Signifier & Meaning & Signified & Type of Symbol \\
\hline Manu & Rooster & Spirit of ancestor & $\begin{array}{c}\text { Lexical Symbol } \\
(\mathrm{N})\end{array}$ \\
\hline Pesta & Party & $\begin{array}{c}\text { Custom } \\
\text { ceremony ; } \\
\text { Inauguration of } \\
\text { The King, Bawa } \\
\text { Maso Harta } \\
\text { Negeri } \\
\text { ceremony, death } \\
\text { ceremony, etc) }\end{array}$ & $\begin{array}{l}\text { Lexical Symbol } \\
(\mathrm{N})\end{array}$ \\
\hline
\end{tabular}

\section{Meanings (Denotation and Connotation)}

'Manu' means a rooster. Denotatively, a rooster is an animal that has two legs, wings, and commonly has power. However connotatively, in culture of Saparua island it is believed that a 'manu' or 'a rooster' is a symbol of god or the spirit of ancestors. 
'Pesta' symbolizes gathering or meeting of all villagers to celebrate a special occasion. Denotatively, a party refers to the one happy modern occasion. However, party here is refer to a custom ceremony that involve either sadness or happiness purpose. For example, the inauguration of king or even the death ceremony that need the existence of the ancestors.

5. Kapata Janji Kapitan (Kapata of Kapitan)

\section{Symbols :}

The symbols are in form of Clausal Symbol (DC), Phrasal Symbol (VP and NP).

\begin{tabular}{|c|c|c|c|}
\hline Signifier & Meaning & Signified & Type of Symbol \\
\hline ehe lotto mena & $\begin{array}{l}\text { To make } \\
\text { promise }\end{array}$ & Promise & $\begin{array}{c}\text { Clausal Symbol } \\
\text { (DC) }\end{array}$ \\
\hline $\begin{array}{c}\text { kele-kele emu } \\
\text { uhuna sisario }\end{array}$ & $\begin{array}{l}\text { Put hand in } \\
\text { hand }\end{array}$ & $\begin{array}{l}\text { Help each } \\
\text { other }\end{array}$ & $\begin{array}{c}\text { Phrasal Symbol } \\
\text { (VP) }\end{array}$ \\
\hline e sa tehe elu & $\begin{array}{l}\text { Same } \\
\text { status, } \\
\text { same } \\
\text { position }\end{array}$ & $\begin{array}{l}\text { A balance } \\
\text { of life }\end{array}$ & $\begin{array}{c}\text { Phrasal Symbol } \\
\text { (NP) }\end{array}$ \\
\hline
\end{tabular}

a) ehe lotto mena

(to make a promise)

to inf. $\mathrm{V}+\mathrm{Det}+\mathrm{N}$

b) kele-kele emu uhuna sisario

(put hand in hand)

$\mathrm{V}+\mathrm{N}+$ Prep. $+\mathrm{N}$

c) e sa tehe elu

(Same Status)

\section{$\operatorname{Adj}+\mathrm{N}$}

\section{Meaning (Denotation and Connotation)}

kele-kele emu uhuna sisario denotatively means we must put hand in hand. However the connotative meaning inside this phrase is that we need to help each other to lift up the burden in this case to win the battle.

e sa tehe elu denotatively means same status, same position. In fact, this phrase is not just an ordinary phrase. It gives a deep message that in facing enemies. Each person has the same task, same right, same obligation which is to protect the village.

\section{Conclusion}

Kapata is one of the oral traditions in Maluku that entirely facing the extinction. It is proven that each village only has one Kapata singer who knows the terminologies and meaning in Tana language. After conducting the analyses, researcher draws the conclusion. First, in Saparua island there are two main types namely Customary Kapata 
and Regular Kapata. Second, it is obviously seen that Kapata oral tradition texts in Saparua island are generally contained Lexical symbol and Phrasal symbol. Lexical symbols obtained in Kapata texts are mostly in Noun (N) which about custom terminology such as manu, pesta, intan paramata, and so on. Nevertheless, the result shows the significant number of phrasal symbol category. This category describes some symbols in form of phrase such as koku lima yapakali, nyora-nyora intan paramata and so on. In addition, the phrasal symbols found are in form of Noun Phrase and Verb Phrase. In addition, the Clausal Symbol in dependent clause form and Sentential Symbol are also exist in the texts of Kapata.

\section{References}

Latupapua, Falantino E. et al. (2012). Kapata, Sastra Lisan di Maluku Tengah. Balai Pengkajian Nilai Budaya Ambon.

Letlora, Prihe.S., (2016). Getting to know Kapata, the Oral Tradition of Maluku., Vol. I

ISBN 978-602-60462-1-5., FIBUH Press., Makassar

Peirce, Charles Sanders (1931-58). Collected Papers (8 vols: vol. 1) Principles of Philosophy, Ed.

Petrus, Simon. (2012). Teks Singgi dan Peranan Tongkonan bagi Masyarakat Sillanan Tana Toraja: Analisis Semiotika. Universitas Hasanuddin. Unpublished Thesis.

Sapir, Edward. (1921). Language: Introduction to the Study of Speech. New York: Harcourt

Teeuw, A. (1994). Indonesia Antara Kelisanan dan Keberaksaraan. Jakarta: Pustaka Jaya Vansina, J. (2014). Tradisi Lisan Sebagai Sejarah. Yogyakarta

Zimmer, Heinrich. (1962). Myths and Symbols in Indian Art and Civilization. New York: Harper Torchbooks. 